\title{
Effect of aluminum source on flexural strength of mullite-bonded porous silicon carbide ceramics
}

\author{
B. V. Manoj KUMAR, Jung-Hye EOM, Young-Wook KIM, In-Sub HAN* and Sang-Kuk WOO*
}

Department of Materials Science and Engineering, the University of Seoul, 90, Jeonnong-dong, Dongdaemun-gu, Seoul 130-743, Korea *Energy Materials Research Center, Korea Institute of Energy Research, 71-2, Jang-dong, Yuseong-gu, Daejeon 305-343, Korea

In the present work, four aluminum sources $\left(\mathrm{Al} / \mathrm{AIN} / \mathrm{Al}_{2} \mathrm{O}_{3} / \mathrm{Al}(\mathrm{OH})_{3}\right)$ were used to fabricate mullite-bonded porous $\mathrm{SiC}$ ceramics via reaction sintering in air at $1450^{\circ} \mathrm{C}$ and $1550^{\circ} \mathrm{C}$ for $1-6 \mathrm{~h}$ duration, and the role of aluminum source on microstructure and strength was estimated. The microstructures revealed a variation in necking and adhesion characteristics of $\mathrm{SiC} / \mathrm{mullite} / \mathrm{silica}$ grains. The porosity decreased and strength increased with sintering temperature or time for all specimens, except for the one prepared with $\mathrm{Al}_{2} \mathrm{O}_{3}$. Amongst the investigated, $\mathrm{SiC}$ ceramics prepared with $\mathrm{Al}_{2} \mathrm{O}_{3}$ exhibited the lowest porosity of $17 \%$ and highest specific strength of $19 \mathrm{kN} \cdot \mathrm{m} / \mathrm{kg}$, while the usage of AIN rendered a combination of the highest porosity of $42 \%$ and lowest specific strength of $5 \mathrm{kN} . \mathrm{m} / \mathrm{kg}$. An attempt has been made to qualitatively explain the strength variation of prepared ceramics on the basis of contributing oxidation reactions towards mullitization.

(C)2010 The Ceramic Society of Japan. All rights reserved.

Key-words : SiC, Mullite, Microstructure, Porosity, Mechanical properties

[Received July 21, 2009; Accepted November 19, 2009]

\section{Introduction}

Porous $\mathrm{SiC}$ ceramics with a unique combination of good mechanical properties, thermal- shock resistance and chemical stability are considered to be candidate materials for several applications such as hot gas filters, molten metal filters, diesel particulate filters, catalytic supports, membrane supports for hydrogen separation, gas-burner media, and preforms for production of metal matrix composites. ${ }^{1-4)}$ Porous SiC ceramics can be produced mainly by replica, sacrificial template, and reaction sintering methods. ${ }^{5)-7)}$ Considering the good oxidation resistance and high temperature stability, and small difference in thermal expansion coefficients with $\mathrm{SiC}\left(0.6 \times 10^{-6} / \mathrm{K}\right.$ at $\left.273-1273 \mathrm{~K}\right)$, mullite-SiC composites are expected to exhibit better properties. ${ }^{8)-14)}$ It has been reported that oxidation-derived $\mathrm{SiO}_{2}$ and alumina react in situ to fabricate mullite $\left(3 \mathrm{Al}_{2} \mathrm{O}_{3} .2 \mathrm{SiO}_{2}\right)$-bonded porous $\mathrm{SiC}$ ceramics at $1400-1550^{\circ} \mathrm{C}$ in air. ${ }^{15)-17)}$ During sintering of $\mathrm{SiC}, \mathrm{Al}_{2} \mathrm{O}_{3}$ and graphite powder compacts, graphite is burned out to produce pores and the surface of the $\mathrm{SiC}$ is oxidized to $\mathrm{SiO}_{2}$ at high temperature. Upon increasing the temperature, $\mathrm{SiO}_{2}$ reacts with $\mathrm{Al}_{2} \mathrm{O}_{3}$ to form mullite. ${ }^{15)} \mathrm{A}$ maximum of strength of $28 \mathrm{MPa}$ was obtained with $20 \mu \mathrm{m}$ - starting SiC powder and $\mathrm{Y}_{2} \mathrm{O}_{3}$ sintering additives. ${ }^{16)}$ Eom et al. demonstrated that strength can be increased to $39 \mathrm{MPa}$ for a $37 \%$ porous mullitebonded $\mathrm{SiC}$ ceramics when high alumina content (37 mass\%) was used, without using graphite. ${ }^{18)}$ The same group further reported that strength can be improved to $~ 90 \mathrm{MPa}$ using sub-micron $\mathrm{SiC}$ powders. ${ }^{19)}$ In order to explore the potential, a thorough understanding of the influence of processing chemistry on mechanical properties of these important materials is highly required. It is clear from the literature review ${ }^{11-19)}$ that in situ participation of alumina towards mullitization is significant in improving the strength of the porous ceramics. However, no study has been reported towards estimating the contribution of alumina from

Corresponding author: Y.-W. Kim; E-mail: ywkim@uos.ac.kr various sources of aluminum on the microstructure and mechanical properties of porous mullite-bonded SiC ceramics.

In the above connection, four aluminum sources: aluminum, aluminum nitride, alumina and aluminum hydroxide powders were used in the present work to in situ synthesize mullite phase with $\mathrm{SiC}$ powders via reaction sintering in air and the influence of aluminum source on synthesis of mullite phase, relative density, and flexural strength of porous $\mathrm{SiC}$ ceramics is systematically studied. Coarse $(\sim 65 \mu \mathrm{m}) \mathrm{SiC}$ powders were used in the present study to keep the processing cost low.

\section{Experimental procedure}

Commercially available refractory-grade $\mathrm{SiC}(\sim 65 \mu \mathrm{m}$, Showa Denko K. K.), sub-micron SiC powders $(\sim 0.5 \mu \mathrm{m}$, Norton AS, Norway), $\mathrm{Al}$ ( $3 \mu \mathrm{m}, 99.9 \%$ pure, High Purity Chemicals Osaka), AlN (1.3 $\mu \mathrm{m}$, Grade F, Tokuyama Soda Co.), $\mathrm{Al}_{2} \mathrm{O}_{3}(\sim 0.4 \mu \mathrm{m}$, AKP30, Sumitomo Chemical Co. $)$ and $\mathrm{Al}(\mathrm{OH})_{3}(\sim 2 \mu \mathrm{m}$, Kanto Chemical Co., Inc.) were used as starting materials. Four batches of powder mixtures were prepared with the respective aluminum source content (see Table 1). The initial calculated aluminum content (23. 7 mass\%) in each source as well as the ratio of large $\mathrm{SiC}$ content to sub-micron $\mathrm{SiC}$ content $(2.3: 1)$ were same. All batches were milled separately in polypropylene jar for $24 \mathrm{~h}$

Table 1. Details of Batch Composition, Green Density and Green Porosity of the Investigated Powder Mixtures

\begin{tabular}{|c|c|c|c|c|c|c|c|c|}
\hline \multirow[b]{2}{*}{ Sample } & \multicolumn{6}{|c|}{ Batch composition (mass $\%$ ) } & \multirow{2}{*}{$\begin{array}{l}\text { Green } \\
\text { density } \\
\left(\mathrm{g} / \mathrm{cm}^{3}\right)\end{array}$} & \multirow{2}{*}{$\begin{array}{l}\text { Green } \\
\text { porosity } \\
(\%)\end{array}$} \\
\hline & $\begin{array}{c}\mathrm{SiC} \\
(\sim 65 \mu \mathrm{m})\end{array}$ & $\begin{array}{c}\mathrm{SiC} \\
(\sim 0.5 \mu \mathrm{m})\end{array}$ & $\mathrm{Al}$ & AlN & $\mathrm{Al}_{2} \mathrm{O}_{3}$ & $\begin{array}{c}\mathrm{Al} \\
(\mathrm{OH})_{3}\end{array}$ & & \\
\hline MBSC1 & 53.4 & 22.9 & 23.7 & & & & 1.82 & 40.9 \\
\hline MBSC2 & 47.5 & 20.4 & & 32.1 & & & 1.73 & 45.4 \\
\hline MBSC3 & 44.1 & 18.9 & & & 37.0 & & 2.22 & 35.9 \\
\hline MBSC4 & 36.9 & 15.8 & & & & 47.3 & 1.94 & 34.8 \\
\hline
\end{tabular}


using distilled water and $\mathrm{SiC}$ grinding balls. Polyethylene glycol and polyvinyl alcohol were added as binders. The milled slurry was dried at $100^{\circ} \mathrm{C}$ for $24 \mathrm{~h}$ and uniaxially pressed under a pressure of $50 \mathrm{MPa}$ using $35 \mathrm{~mm} \times 8 \mathrm{~mm}$ mold. The compacts were sintered at $1450{ }^{\circ} \mathrm{C}$ and $1500^{\circ} \mathrm{C}$ for $1 \mathrm{~h}, 2 \mathrm{~h}$ and $6 \mathrm{~h}$ in air. The density of the green compacts and the bulk density of the sintered ceramics were calculated from the weight-to-volume ratio. The porosity was estimated using boiling water. The fracture surface morphology was studied using scanning electron microscopy (SEM, S4300, Hitachi Ltd.). Bar-shaped samples were cut to a size of $3 \mathrm{~mm} \times 4 \mathrm{~mm} \times 30 \mathrm{~mm}$ and bending tests were performed at room temperature on four to five specimens at each condition using a four-point method (Instron 4465, Instron Co., Ltd., USA) with inner and outer spans of 10 and $20 \mathrm{~mm}$, respectively. The specimens were loaded at a constant crosshead speed of $0.5 \mathrm{~mm} /$ min. All surfaces of the sintered samples were polished and subsequently samples were ground using mortar. The powder was sieved (through $600 \mu \mathrm{m}$ ) and the phase analysis conducted using X-ray diffractometry (XRD, D8 Discover, Bruker AXS GmbH, Germany) with $\mathrm{Cu} \mathrm{K} \alpha$ radiation. Differential thermal analysis (DTA) of powder mixtures of varying composition was carried up to $1500^{\circ} \mathrm{C}$ in air with $4^{\circ} \mathrm{C} / \mathrm{min}$ heating/cooling rate using SDT Q600 V7.0 Build 84 (Universal v4.0C TA Instruments) system.

\section{Results}

The effect of aluminum source on phase evolution of the sintered ceramics is shown in Fig. 1(a). A 70 mass $\%$ SiC- 30 mass $\%$ mullite composite powder mixture synthesized at $1600^{\circ} \mathrm{C}$ for 2 $\mathrm{h}$ was used to analyze various phases present in the sintered mullite-bonded porous $\mathrm{SiC}$ ceramics. XRD analysis reveal major peaks of $\alpha$-SiC, mullite, cristobalite, and traces of $\alpha-\mathrm{Al}_{2} \mathrm{O}_{3}$. With increase in temperature from $1450^{\circ} \mathrm{C}$ to $1550^{\circ} \mathrm{C}$, alumina peaks were reduced in intensity. With the traces of alumina peaks, the mullitization reaction is nearly completed when sintered at $1550^{\circ} \mathrm{C}$. However, the phase evolution varied with different aluminum sources used. For the purpose of comparative estimation of the degree of mullitization, the mullite phase content was assessed from the fraction of major peak intensities that appear on the XRD spectrum of the samples sintered at $1550^{\circ} \mathrm{C}$ for $6 \mathrm{~h}$, and presented in Fig. 1(b). It is evident that MBSC 3 possess the highest amount $(26 \%)$ of mullite, while MBSC2 has the lowest mullite (17\%). The MBSC1 and MBSC4 have mullite in between.
The green density measurements of the investigated powder mixtures are shown in Table 1. It is evident that the green density of the MBSC 3 is the highest and that of MBSC2 is the lowest among the investigated ceramics. The green density of the MBSC 1 and MBSC4 are in between. The fine $\mathrm{Al}_{2} \mathrm{O}_{3}$ powder rendered a maximum green density. However, there is no relation between particle size and green density for other specimens. This is probably related to the other characteristics of powder particles such as size distribution and shape. Furthermore, it is evident from Table 1 and Fig. 1(b) that the green porosity and degree of mullitization are generally related. The large degree of particle contacts with the low green porosities in MBSC3 or MBSC4 results in the promoted reaction to yield high mullite content. According to Carter, ${ }^{20)}$ the completeness (kinetics) of solid state diffusion reaction at high temperature to produce a volume of reaction product from a unit volume of reactant is governed by the reactant particle size. Fine particles largely promote the reaction because of the decreased diffusion distances. On the other hand, the growth of the solid state reaction product in powder systems essentially occurs at particle contact points. Thus, combined effect of reactant particle size (due to different aluminum sources) and degree of green body particle contacts (variation in green porosity) in the present study influences the degree of mullitization. Results indicate that fine particle size and low green porosity yield greater mullitization.

Figure 2 shows typical fracture surfaces of porous mullitebonded $\mathrm{SiC}$ ceramics using different sources of aluminum. In general, microstructures of the samples sintered at $1550^{\circ} \mathrm{C}$ for 2 $\mathrm{h}$ reveal large $\mathrm{SiC}$ grains embedded in matrix of fine and loosely bound grains and residual porosity. Since mullitization occurs before densification, the latter is limited to a smaller extent, resulting in structure containing plenty of open pores. ${ }^{21}$ The pores are derived from stacking of $\mathrm{SiC}$ and $\mathrm{Al} / \mathrm{AlN} / \mathrm{Al}_{2} \mathrm{O}_{3} /$ $\mathrm{Al}(\mathrm{OH})_{3}$ particles. The grain size of mullite or silica ranges from 0.5 to $2 \mu \mathrm{m}$, while pore size ranges from 1 to $5 \mu \mathrm{m}$. It is difficult to distinguish the grains in these microstructures. Amongst the investigated ceramics, MBSC 3 exhibits strongest microstructure of well connected small mullite/silica particles that attached with large $\mathrm{SiC}$ grains (Fig. 2(c)). The shrinkage is also the higher for this sample, rendering the lowest porosity. On the other hand, MBSC1 consists of very loosely bound particles with minimal necking, suggesting less strength (Fig. 2(a)). In case of MBSC2, less shrinkage results in increased porosity (Fig. 2(b)). The

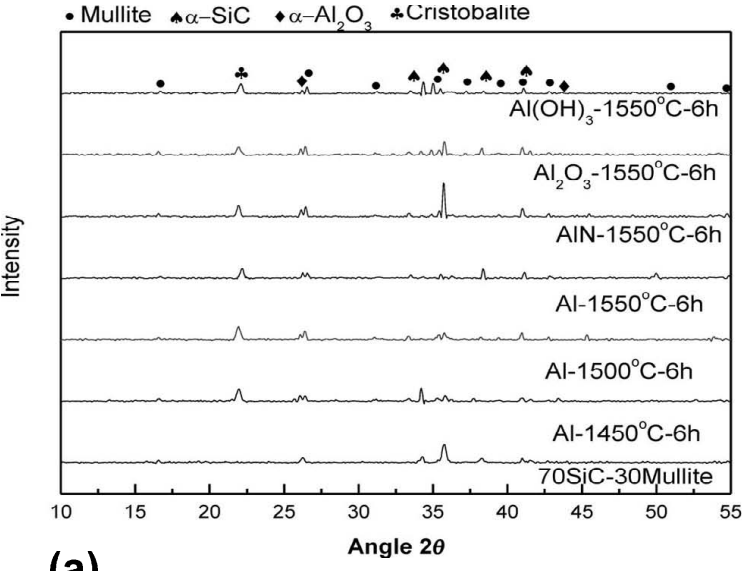

(a)

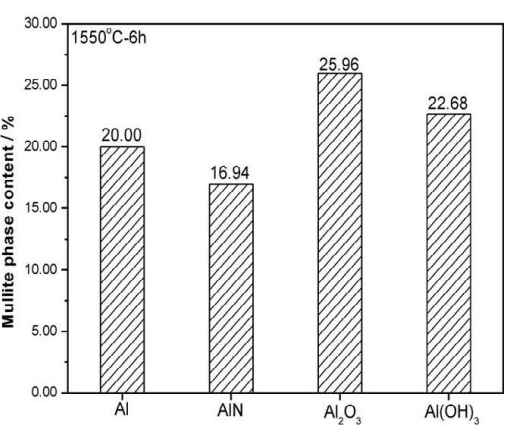

(b)

Fig. 1. (a) Phase analysis of the porous mullite-bonded SiC ceramics and (b) mullite phase content of the ceramics sintered at $1550^{\circ} \mathrm{C}$ for $6 \mathrm{~h}$. 

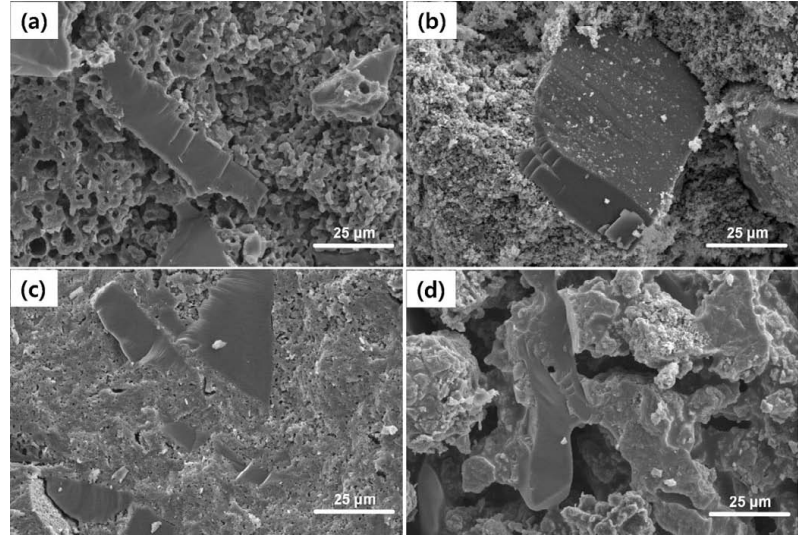

Fig. 2. Typical fracture surfaces of the porous mullite-bonded $\mathrm{SiC}$ ceramics sintered at $1550^{\circ} \mathrm{C}$ for $2 \mathrm{~h}$ in air with various aluminum sources: (a) $\mathrm{Al}$, (b) $\mathrm{AlN}$, (c) $\mathrm{Al}_{2} \mathrm{O}_{3}$ and (c) $\mathrm{Al}(\mathrm{OH})_{3}$.
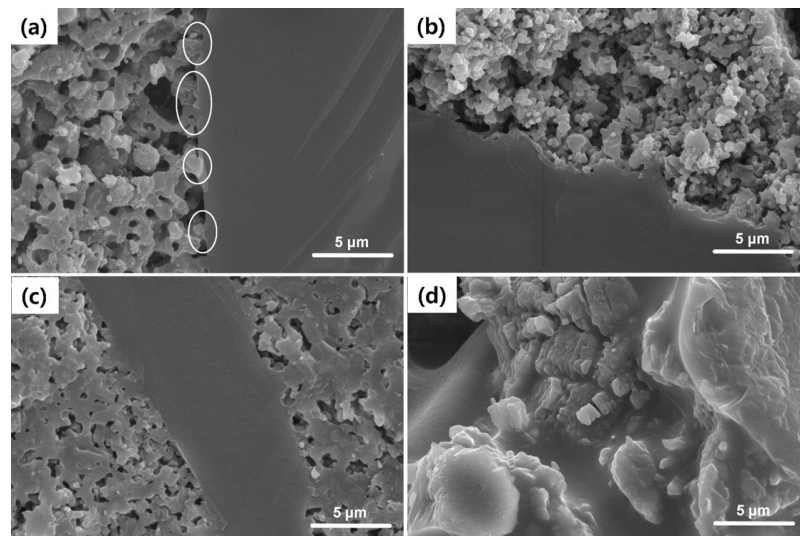

Fig. 3. Bonding characteristics of the porous mullite-bonded SiC ceramics sintered at $1550^{\circ} \mathrm{C}$ for $2 \mathrm{~h}$ in air with various aluminum source: (a) $\mathrm{Al}$, (b) $\mathrm{AlN}$, (c) $\mathrm{Al}_{2} \mathrm{O}_{3}$ and (c) $\mathrm{Al}(\mathrm{OH})_{3}$. Ellipse marks indicate discontinuous bonding.

microstructure of MBSC4 seems to be different (Fig. 2(d)). The small particles are strongly necked but weakly attached with large $\mathrm{SiC}$ grains. Moreover, pore size is tremendously increased. Another important observation is that the large grains are fractured predominantly by transgranular mode in MBSC3, MBSC1 or MBSC4 sample, while pull-out of large $\mathrm{SiC}$ grain indicates intergranular fracture in MBSC2.

The influence of aluminum source on the bonding characteristics of grain interface of ceramics sintered at $1550^{\circ} \mathrm{C}$ for $2 \mathrm{~h}$ is further explored in Fig. 3. The discontinuous bonding (marked with ellipses in Fig. 3(a)) of small mullite/silica grains with large $\mathrm{SiC}$ grains can be found in MBSC1, while intimate adhesion of well connected small grains with large $\mathrm{SiC}$ grains can be observed in MBSC3. On the other hand, the small particles with weak necking are poorly attached with the large $\mathrm{SiC}$ grains in MBSC2 (Fig. 3(b)). In case of MBSC4, the particles are strongly connected but weakly attached with large $\mathrm{SiC}$ grains, resulting in an increased pore size (Fig. 3(d)). The strongest adhesion of highly necked particles with large $\mathrm{SiC}$ grains is expected to impart high strength in case of MBSC3 (Fig. 3(c)).

The influence of sintering duration on microstructural characteristics is shown in Fig. 4. The prolonged sintering results in densification at local regions, attributed to the more amount of
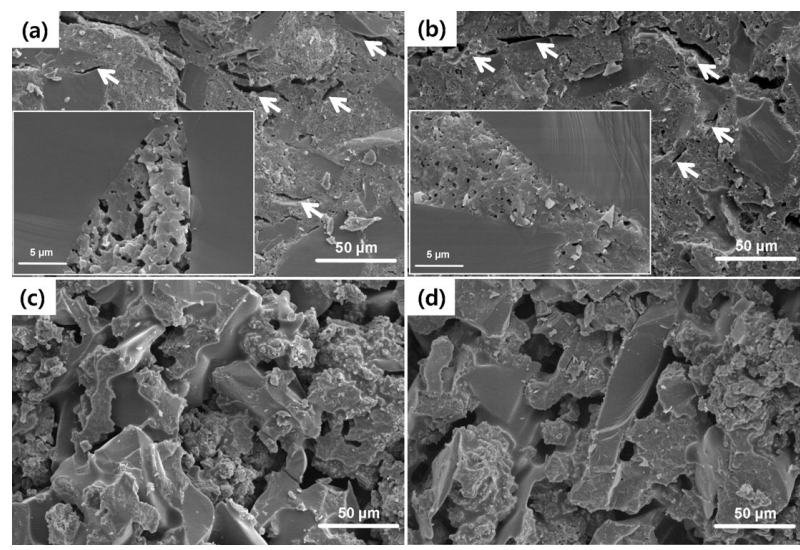

Fig. 4. Typical fracture surfaces of the MBSC3 specimen sintered for (a) $1 \mathrm{~h}$ (b) $6 \mathrm{~h}$, and MBSC4 specimen sintered for (c) $1 \mathrm{~h}$ and (d) $6 \mathrm{~h}$ in air at $1550^{\circ} \mathrm{C}$. Insets in (a) and (b) show the bonding characteristics. Arrows indicate extensive cracking.

mullite phase. The increased adhesion between small grains and large $\mathrm{SiC}$ grains with prolonged sintering duration can be noted in insets of Figs. 4(a) and (b). However, the evidence of enhanced cracking (marked with arrows in Figs. 4(a) and (b)) with sintering duration of MBSC 3 might circumvent the strength improvement by certain extent. In MBSC4 sample, the increased duration enhanced the necking of small particles but large pore size is still observed, without obvious attachment of large SiC grains (Figs. 4(c) and (d)).

The porosity measurements are shown in Fig. 5. The porosity varied from $17-42 \%$ with the variation in the aluminum source and sintering conditions. When sintered at $1450^{\circ} \mathrm{C}, \mathrm{MBSC} 3$ render minimum porosity, while MBSC4 provides maximum amongst the investigated specimens. The increase in sintering temperature reduced porosity by $1-7 \%$, whereas duration caused reduction by $1-5 \%$. Thus, a minimum porosity of $\sim 17 \%$ was recorded for MBSC3 sintered for $6 \mathrm{~h}$, whereas a maximum porosity of $42 \%$ was measured for MBSC 2 sintered for $1 \mathrm{~h}$ duration at $1450{ }^{\circ} \mathrm{C}$. When sintered at $1550^{\circ} \mathrm{C}, \mathrm{MBSC} 2$ exhibited a maximum porosity of $40 \%$ after $1 \mathrm{~h}$ and MBSC 3 rendered a minimum porosity of $17 \%$ after $6 \mathrm{~h}$. Overall, MBSC 3 has a minimum amount of porosity and MBSC2 has maximum, and MBSC1 and MBSC4 have porosities in between, irrespective of the sintering conditions.

In order to avoid the shrinkage effect in understanding the influence of aluminum source, the variation of specific flexural strength of the mullite-bonded $\mathrm{SiC}$ composites sintered at different sintering conditions is shown in Fig. 6. It is evident that specific strength varied in a range of $5-19 \mathrm{kN} . \mathrm{m} / \mathrm{kg}$ for the developed ceramics. Among the investigated specimens, MBSC2 exhibited poor strength of $5 \mathrm{kN} . \mathrm{m} / \mathrm{kg}$, while MBSC 3 exhibited a high strength level of $19 \mathrm{kN} . \mathrm{m} / \mathrm{kg}$ when sintered at $1450^{\circ} \mathrm{C}$ for $1 \mathrm{~h}$. When sintered at high temperature, the specific strength increased by $1-5 \mathrm{kN} . \mathrm{m} / \mathrm{kg}$ for all specimens, except MBSC3. A reduction of $4-5 \mathrm{kN} \cdot \mathrm{m} / \mathrm{kg}$ was observed for MBSC3 with increase in temperature from $1450^{\circ} \mathrm{C}$ to $1550^{\circ} \mathrm{C}$. With increase in duration, the specific strength in general increased.

The variation in strength can be related to the observed microstructural characteristics of the sintered specimens. MBSC3 microstructure with strong network of mullite/silica grains that strongly adhere with large SiC grains imparts highest strength. MBSC1 microstructure with weakly connected grains and dis- 

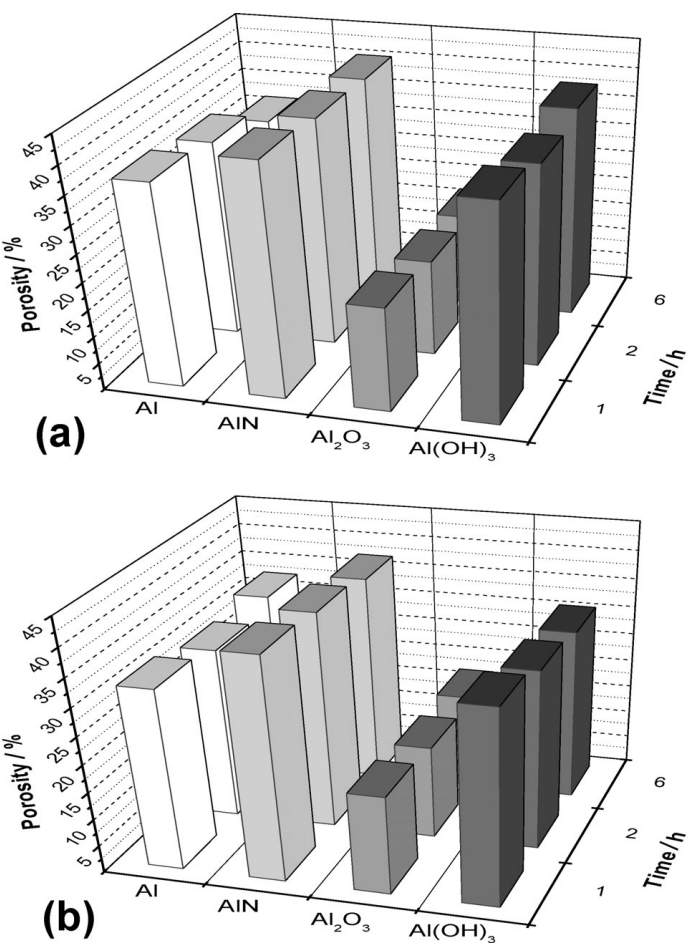

Fig. 5. Effects of $\mathrm{Al}$ source and sintering time on porosity of porous mullite-bonded $\mathrm{SiC}$ ceramics: (a) $1450^{\circ} \mathrm{C}$ and (b) $1550^{\circ} \mathrm{C}$.

continuous adhesion result in the low strength than MBSC3. MBSC4 sample consisting of strong necking of small grains with weak adhesion to the large $\mathrm{SiC}$ grains provide large porosity. The increased defect (pore) size helps to easy crack propagation that renders less strength. The very loose structure of mullite/silica grains and their poor adhesion with large $\mathrm{SiC}$ grains offers lowest strength in case of MBSC2. The intergranular fracture observed in MBSC2 also indicates its poor strength when compared with transgranular fracture in other samples.

\section{Discussion}

As the sinterability or strength of the sintered specimens is claimed to be largely affected by the packing density of the green body ${ }^{22)-24)}$ the influence of aluminum source on the relationship between green density and porosity, density or strength of the sintered specimens in the present study can be discussed. In general, compacts of low green density resulted in high sintered porosity, regardless of the sintering temperature and duration. Typical relation between green density and sintered porosity of the specimens sintered at $1550^{\circ} \mathrm{C}$ for $6 \mathrm{~h}$ is provided in Fig. 7(a). MBSC2 specimen prepared with the compacts of lowest green density of $1.73 \mathrm{~g} / \mathrm{cm}^{3}$ consisted of a maximum porosity of $\sim 37 \%$, while MBSC3 specimen prepared with compacts of highest green density of $2.22 \mathrm{~g} / \mathrm{cm}^{3}$ exhibited a minimum porosity of $\sim 17 \%$. However, the corresponding relationship between the green density and sintered density of the specimen is not observed (Fig. 7(b)). Particularly, $1.94 \mathrm{~g} / \mathrm{cm}^{3}$ green density resulted in a low sintered density of $1.85 \mathrm{~g} / \mathrm{cm}^{3}$ in case of MBSC4, when compared against $1.82 \mathrm{~g} / \mathrm{cm}^{3}$ green density and $1.86 \mathrm{~g} / \mathrm{cm}^{3}$ sintered density for MBSC1. This deviation in case of MBSC4 is also observed in relationship between green porosity and sintered porosity (Fig. 7(c)). The weight loss due to decomposition of $\mathrm{Al}(\mathrm{OH})_{3}$ during sintering is probably responsible for the observed low density for MBSC4. Furthermore, MBSC1

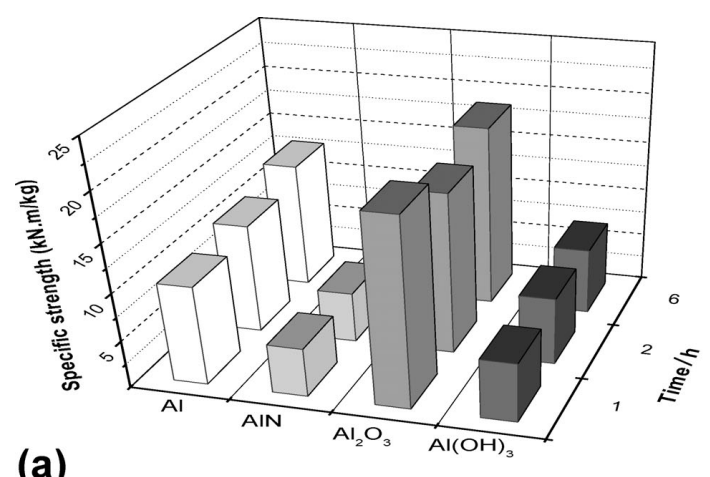

(a)

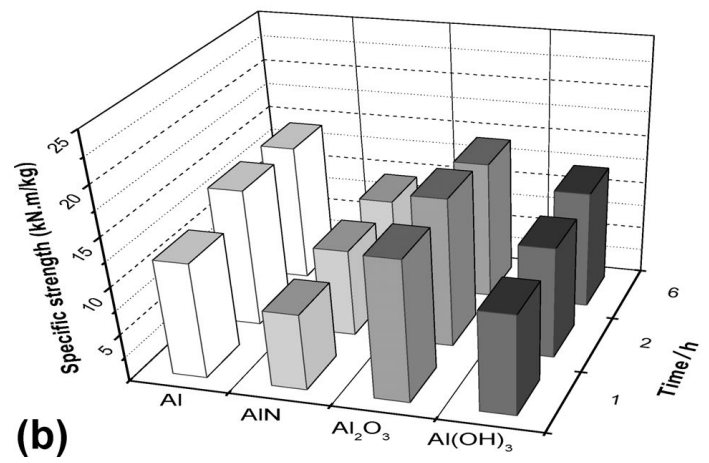

Fig. 6. Effects of Al source and sintering time on specific strength of porous mullite-bonded $\mathrm{SiC}$ ceramics: (a) $1450^{\circ} \mathrm{C}$ and (b) $1550^{\circ} \mathrm{C}$.

specimen prepared with the green density of $1.82 \mathrm{~g} / \mathrm{cm}^{3}$ showed high strength of $\sim 27 \mathrm{MPa}$ when compared against $23 \mathrm{MPa}$ strength and $1.94 \mathrm{~g} / \mathrm{cm}^{3}$ density for MBSC4 (Fig. 7(d)). The observed high strength for MBSC1 can be attributed to the greater feasibility of alumina formation. These results necessarily suggest that porosity is largely determined by the green density regardless of the aluminum source, while composition of the staring powder mixture (aluminum source) also influences the density or strength of the sintered $\mathrm{SiC}$ ceramics via variety of sintering reactions.

The formation of mullite phase in between $\mathrm{SiC}$ grains can be explained on the basis of in situ reactions. $\mathrm{SiC}$ oxidizes to amorphous silica that further crystallizes to form cristobalite during sintering at high temperatures in $\operatorname{air}^{25)}$ as

$$
\begin{aligned}
& \mathrm{SiC}+2 \mathrm{O}_{2} \rightarrow \mathrm{SiO}_{2} \text { (amorphous) }+\mathrm{CO}_{2}(\mathrm{~g}) \\
& \text { Amorphous } \mathrm{SiO}_{2} \rightarrow \text { Cristobalite }
\end{aligned}
$$

Simultaneously, the alumina is formed from various sources as per the following oxidation reactions:

$$
\begin{aligned}
& 2 \mathrm{Al}+1.5 \mathrm{O}_{2}(\mathrm{~g}) \rightarrow \mathrm{Al}_{2} \mathrm{O}_{3} \\
& 2 \mathrm{AlN}+1.5 \mathrm{O}_{2}(\mathrm{~g}) \rightarrow \mathrm{Al}_{2} \mathrm{O}_{3}+\mathrm{N}_{2}(\mathrm{~g}) \\
& 2 \mathrm{Al}(\mathrm{OH})_{3} \rightarrow \mathrm{Al}_{2} \mathrm{O}_{3}+3 \mathrm{H}_{2} \mathrm{O}(\mathrm{g})
\end{aligned}
$$

The cristobalite reacts with alumina/derived-alumina upon increasing the temperature (beyond $1400^{\circ} \mathrm{C}$ ) to form mullite according to: ${ }^{8), 15)}$

$$
3 \mathrm{Al}_{2} \mathrm{O}_{3}+2 \mathrm{SiO}_{2} \rightarrow 3 \mathrm{Al}_{2} \mathrm{O}_{3} .2 \mathrm{SiO}_{2} \text { (mullite) }
$$

The mullitization is followed by the partial liquid phase sintering that is responsible for densification. The in situ synthesized mullite acts as an adhesive, bonding the $\mathrm{SiC}$ particles together, as observed in Figs. 2-4. Figure 8 represents DTA 

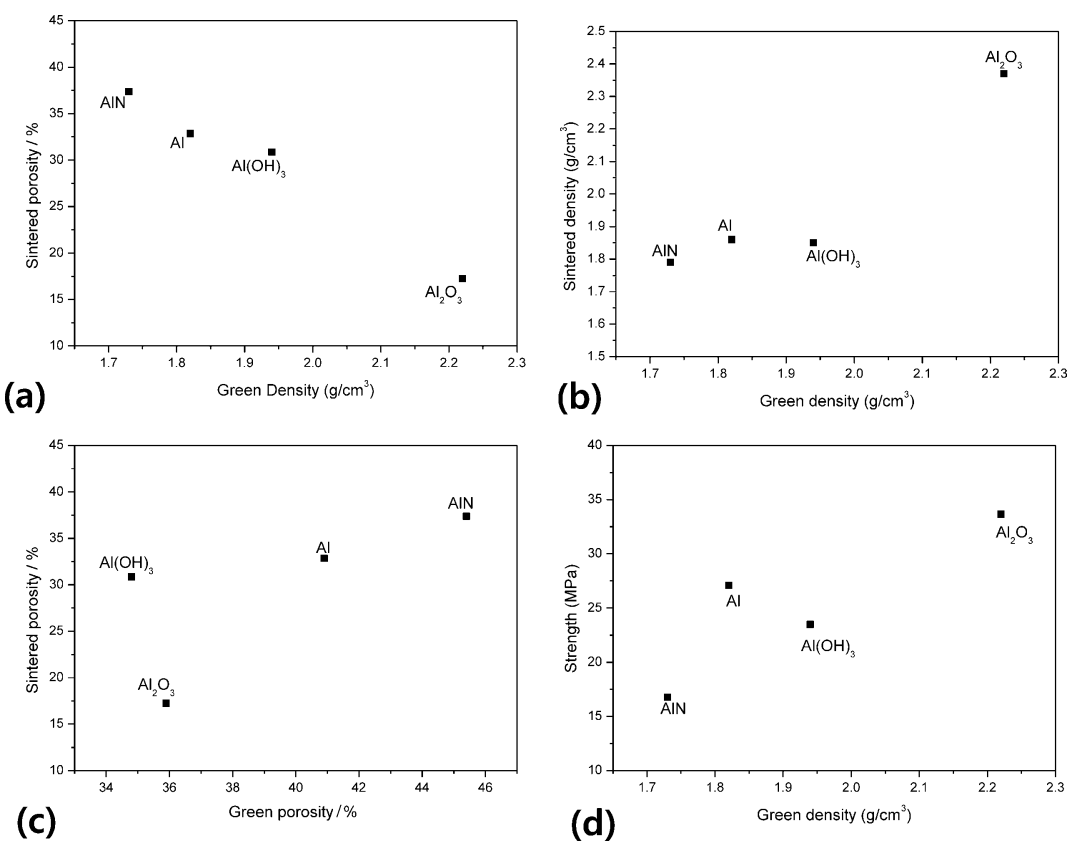

Fig. 7. The relationship between (a) green density and sintered porosity, (b) green density and sintered density, (c) green porosity and sintered porosity, and (d) green density and strength of the specimens sintered at $1550^{\circ} \mathrm{C}$ for $6 \mathrm{~h}$.

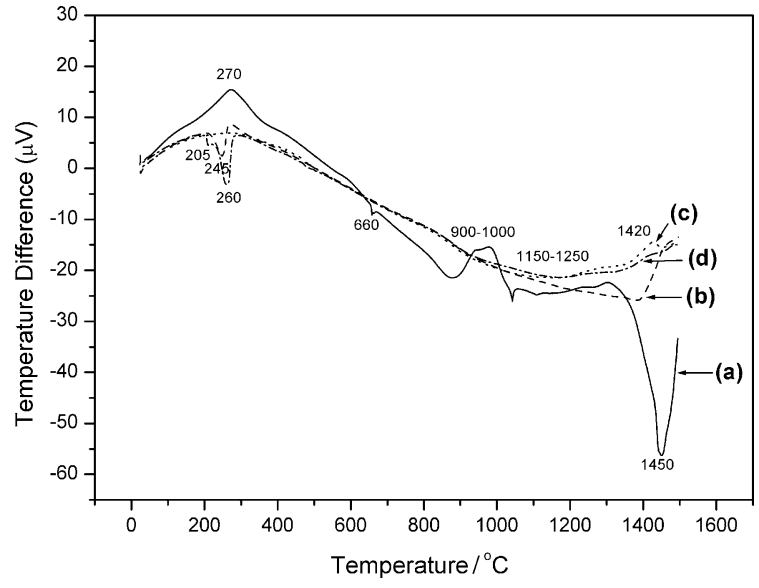

Fig. 8. DTA curves of the powder mixtures containing various aluminum sources: (a) $\mathrm{Al}$, (b) $\mathrm{AlN}$, (c) $\mathrm{Al}_{2} \mathrm{O}_{3}$ and (d) $\mathrm{Al}(\mathrm{OH})_{3}$.

curves of the investigated powder mixtures that differ in aluminum sources: $\mathrm{Al}, \mathrm{AlN}, \mathrm{Al}_{2} \mathrm{O}_{3}$ and $\mathrm{Al}(\mathrm{OH})_{3}$. Endothermic peaks at $205^{\circ} \mathrm{C}$ (curve (d)) and $245^{\circ} \mathrm{C}$ (curve (b)) represent respective decomposition reactions of $\mathrm{Al}(\mathrm{OH})_{3}$ and $\mathrm{AlN}$ (Eq. 4), while large endothermic peak at $260^{\circ} \mathrm{C}$ (curve (d)) indicates the dehydration reaction of $\mathrm{Al}(\mathrm{OH})_{3}$ (Eq. 5). The appearance of sharp exothermic peak at $270^{\circ} \mathrm{C}$ (curve (a)) represents rapid solid state oxidation of $\mathrm{Al}$ particles (Eq. 3) whereas shallow peak at around $245^{\circ} \mathrm{C}$ (curve (c)) reveals greater stability of $\mathrm{Al}_{2} \mathrm{O}_{3}$ particles. The endothermic peak at $660^{\circ} \mathrm{C}$ (curve (a)) essentially indicates the melting of Al. Upon further heating, the presence of shallow exothermic peak in the temperature range of $900-1000^{\circ} \mathrm{C}$ (curve (a)) indicates the oxidation of molten Al. This can be thought also as a result of the oxidation of inner part of the particles that was protected by the oxide layer that formed due to initial solid state oxidation at $270^{\circ} \mathrm{C}$. The shallow peak in the range of 1150 $1250^{\circ} \mathrm{C}$ in all curves indicate the oxidation of $\mathrm{SiC}$ particles (Eq. 1). Oxidation of $\mathrm{SiC}$ at lower temperature (usually occurs beyond $\left.1350^{\circ} \mathrm{C}\right)^{26)}$ is due to the increased reaction kinetics caused by the large surface area of submicron particles. The exothermic peak at $1420^{\circ} \mathrm{C}$ (curve (c)) represents the mullitization reaction (Eq. 6) when $\mathrm{Al}_{2} \mathrm{O}_{3}$ particles were used. The observed temperature is consistent with the reported mullite reaction temperature range of $1400-1450^{\circ} \mathrm{C}^{15), 27)}$ However such a distinguishable peak does not exist in the DTA curves of other powder mixtures upto the maximum temperature studied $\left(1500^{\circ} \mathrm{C}\right)$. The increase in the slopes of the curves indicate the onset of mullitization (Eq. 6) however, absence of distinguishable peak within the $1500^{\circ} \mathrm{C}$ represents the incompleteness. The onset of the mullite reaction is estimated as $1370^{\circ} \mathrm{C}$ (curve (d)), $1390^{\circ} \mathrm{C}$ (curve (b)) and beyond $1500^{\circ} \mathrm{C}$ (curve (a)) for the respective powder mixtures containing $\mathrm{Al}(\mathrm{OH})_{3}, \mathrm{AlN}$ and $\mathrm{Al}$. The presence of sharp endothermic peak at $1450^{\circ} \mathrm{C}$ for $\mathrm{Al}$ is not understood. Overall, it is evident that the reaction temperatures are significantly different with the compositional variation of powder mixtures thus influencing the microstructure and mechanical properties of mullite-bonded SiC ceramics.

Furthermore, XRD analysis (not shown) of the submicron $\mathrm{SiC}$ particles heated upto $1550^{\circ} \mathrm{C}$ for $6 \mathrm{~h}$ in air revealed the predominant presence of cristobalite and a small amount ( 15\%) of retained $\mathrm{SiC}$ phase. Since the amount of submicron $\mathrm{SiC}$ particles in the initial powder mixtures is same in the present study, the role of their oxidation in influencing the degree of mullitization is expected be insignificant. Thus, small grains in Figs. 2-4 are mainly mullite/silica/SiC that attached with the large $\mathrm{SiC}$ grains. The mullitization between $\mathrm{SiO}_{2}$ and $\mathrm{Al}_{2} \mathrm{O}_{3}$ can be explained by the solution-precipitation mechanism. ${ }^{28), 29)}$ Due to the superficial softening, the $\mathrm{Al}_{2} \mathrm{O}_{3}$ particles penetrate into the viscous $\mathrm{SiO}_{2}$ glass, leading to the nucleation of mullite. At increased temperature, viscosity of $\mathrm{SiO}_{2}$ glass decreases and more $\mathrm{Al}^{3+}$ ions are dissolved into the $\mathrm{SiO}_{2}$ glass. The mullite formation is accelerated because of the short diffusion distances and is diffusion controlled. ${ }^{16)}$ Accordingly, strength improved in general with temperature or time except for MBSC3. While, readily available alumina is consumed to a larger extent in MBSC3, the SiC-rich composition cause deficiency in alumina for further mullitization 
resulting in the excessive amount of residual cristobalite $\mathrm{SiO}_{2}$. The phase transformation of cristobalite from tetragonal to cubic induces cracks (see Fig. 4) in sintered specimen during cooling. Moreover, the excessive amount of cristobalite is harmful to high temperature properties of porous $\mathrm{SiC}$ ceramics because of its large coefficient of thermal expansion $\left(17.5 \times 10^{-6} / \mathrm{K}\right.$ at $\left.\left.20-700^{\circ} \mathrm{C}\right) .{ }^{16}\right)$ Thus, strength is reduced with increase in temperature or time for MBSC3. The poor strength of MBSC2 sample can be understood from the oxidation of $\mathrm{AlN}$. The oxidation of $\mathrm{AlN}$ to $\mathrm{Al}_{2} \mathrm{O}_{3}$ is highly favored above $1100^{\circ} \mathrm{C}$ in oxidizing atmospheres as per Eq. $4{ }^{30)}$ It is to note that the oxidation of AlN is largely affected by the simultaneous oxidation of $\mathrm{SiC}$ from the $\mathrm{SiC}$-rich composition in the present study. It has been reported that high temperature oxidation of the AlN can be effectively suppressed in the presence of silica. ${ }^{31)}$ Accordingly, silica derived from $\mathrm{SiC}$ particles in the present system also protects AlN particles from oxidation due to the inhibition of transport of oxidants $\left(\mathrm{O}_{2}\right)$. Thus, limited amount of alumina is available for the mullitization to occur and responsible for the lowest strength levels observed in case of MBSC2 (Fig. 6).

Summarizing, porosity of mullite-bonded porous $\mathrm{SiC}$ ceramics could be related to the green density of powder mixture, while influence of aluminum source was significant in assessing the sintered density, mullitization or strength. The high degree of mullitization from the readily available alumina in MBSC3 resulted in the highest strength values, whereas oxidation-derived alumina in MBSC1 rendered relatively low strength. The suppressed oxidation of AlN in presence of silica effectively reduced the mullitization and thereby strength to the lowest levels for MBSC2. The strength increased with sintering temperature and duration due to the accelerated diffusion of oxygen through silica for MBSC1, MBSC2 and MBSC4, while the excessive amount of residual cristobalite was attributed to the reduced strength in case of MBSC3. In the backdrop of above considerations and based on the experimental results obtained, it can be mentioned that the AlN shall not be used for fabricating stronger porous mullite-bonded $\mathrm{SiC}$ ceramics via reaction sintering.

\section{Conclusions}

Mullite-bonded porous $\mathrm{SiC}$ ceramics were fabricated using different aluminum sources: $\mathrm{Al}, \mathrm{AlN}, \mathrm{Al}_{2} \mathrm{O}_{3}$ and $\mathrm{Al}(\mathrm{OH})_{3}$ via reaction sintering in air at $1450^{\circ} \mathrm{C}$ and $1550^{\circ} \mathrm{C}$ for $1 \mathrm{~h}, 2 \mathrm{~h}$ and $6 \mathrm{~h}$ duration. The role of aluminum source on the mullitization, microstructural development and strength was assessed. The following are the major conclusions:

(a) The mullitization increased with sintering temperature and almost completed when sintered at $1550^{\circ} \mathrm{C}$. The sintering duration increased the mullitization for all specimens.

(b) The microstructures in general consisted of loose grain structure with obvious pores. The mullite-silica grains were well connected and strongly adhered with large $\mathrm{SiC}$ grains in samples fabricated using $\mathrm{Al}_{2} \mathrm{O}_{3}$ source, whereas samples prepared with AlN source showed poor adhesion and weak bonding.

(c) A minimum porosity of $17 \%$ was measured for the sample prepared with $\mathrm{Al}_{2} \mathrm{O}_{3}$ source when sintered at $1550^{\circ} \mathrm{C}$ for $6 \mathrm{~h}$, while a maximum porosity of $42 \%$ measured for the samples prepared with AlN source when sintered at $1450^{\circ} \mathrm{C}$ for $1 \mathrm{~h}$.

(d) High specific strength levels of $14-19 \mathrm{kN} . \mathrm{m} / \mathrm{kg}$ were measured for samples fabricated using $\mathrm{Al}_{2} \mathrm{O}_{3}$ source, while samples prepared with AlN source rendered poor strength levels of $5-9 \mathrm{kN} . \mathrm{m} / \mathrm{kg}$ with varying sintering conditions.

(e) The variation in the strength can be largely explained on the basis of contribution of sintering reactions towards mullitization.

Acknowledgements This work was supported by the Energy Resources Technology Development Program of the Ministry of Knowledge Economy, Republic of Korea.

\section{References}

1) D. J. Green and P. Colombo, MRS Bull., 28, 296-300 (2003).

2) P. Greil, Adv. Mater., 14, 709-716 (2002).

3) S. Kitaoka, Y. Matsushima, C. Chen and H. Awaji, J. Am. Ceram. Soc., 87, 906-913 (2004).

4) X. Zhu, D. Jiang and S. Tan, Mater. Sci. Eng. A, 323, 232238 (2002).

5) J.-H. Eom, Y.-W. Kim, I. H. Song and H. D. Kim, J. Eur. Ceram. Soc., 28, 1029-1035 (2008).

6) J. F. Yang, G. J. Zhang, N. Kondo, J. H. She, Z. H. Jin, T. Ohji and S. Kanzaki, J. Am. Ceram. Soc., 86, 910-914 (2003).

7) Y.-W. Kim, S. H. Kim, I. H. Song, H. D. Kim and C. B. Park, J. Am. Ceram. Soc., 88, 2949-2951 (2005).

8) I. A. Aksay, D. M. Dabbs and M. Sarikaya, J. Am. Ceram. Soc., 74, 2343-2358 (1991).

9) H. R. Rezaie, W. M. Rainforth and W. E. Lee, J. Eur. Ceram. Soc., 19, 1777-1787 (1999).

10) M. I. Osendi, J. Mater. Sci., 25, 3561-3565 (1990).

11) B. Saruhan, W. Albers, H. Schneider and W. A. Kaysser, J. Eur. Ceram. Soc., 16, 1075-1081 (1996).

12) A. P. S. Rana, O. Aiko and J. A. Pask, Ceram. Int., 8, 151153 (1982)

13) Y. Hirata, S. Matsushita, Y. Ishihara and H. Katsuki, J. Am. Ceram. Soc., 74, 2438-2442 (1991).

14) M. Schmticker, W. Albers and H. Schneider, J. Eur. Ceram. Soc., 14, 511-515 (1994).

15) S. Ding, S. Zhu, Y. Zeng and D. Jiang, Ceram. Int., 32, 461466 (2006)

16) S. Ding, S. Zhu, Y. Zeng and D. Jiang, J. Eur. Ceram. Soc., 27, 2095-2102 (2007).

17) S. Ding, Y. P. Zen and D. Jiang, J. Phys. D: Appl. Phys., 40, 2138-2142 (2007).

18) J.-H. Eom, Y.-W. Kim and S.-K. Woo, J. Ceram. Proc. Res., 10, s82-s86 (2009).

19) J.-H. Eom, Y.-W. Kim, S.-K. Woo and I.-S. Han, J. Ceram Soc. Japan, 117, 421-425 (2009).

20) (a) R. E. Carter, J. Chem. Phys., 34, 2010-2015 (1961). (b) R. E. Carter, J. Chem. Phys., 35, 1137-1138 (1961).

21) Y. Nurishi and J. A. Pask, Ceram. Int., 8, 57-59 (1982).

22) H. Takahashi, N. Shinohara, K. Uematsu and J. Tsubaki, J. Am. Ceram. Soc., 79, 843-848 (1996).

23) Y. Zhang, M. Inoue, N. Uchida and K. Uematsu, J. Mater. Res., 14, 3370-3374 (1999).

24) N. Shinohara, S. Katori, M. Okumiya, T. Hotta, K. Nakahira, M. Naito, Y.-I. Cho and K. Uematsu, J. Eur. Ceram. Soc., 22, 2841-2848 (2002).

25) P. J. Jorgensen, M. E. Wadsworth and I. B. Cutler, J. Am. Ceram. Soc., 42, 613-616 (1959).

26) V. A. Lavrenko, E. A. Pugach, S. I. Filipchenko and Y. G. Gogotsi, Oxid. Met., 27, 83-93 (1987).

27) S. Wu, H. M. Chan and M. P. Harmer, J . Am. Cer. Soc., 80, 1579-1582 (1997).

28) R. F. Davis and J. A. Pask, J. Am. Ceram. Soc., 55, 525-531 (1972).

29) P. Mechnich, H. Scheider, M. Schmucker and B. Saruhan, $J$. Am. Ceram. Soc., 81, 1931-1937 (1998).

30) V. A. Lavrenko and A. F. Alexeev, Ceram. Int., 9, 80-82 (1983).

31) Y.-H. Koh, J.-J. Choi and H.-E. Kim, J. Am. Ceram. Soc., 83, 306-310 (2000). 